\title{
Masalah Emosi dan Perilaku pada Anak dan Remaja di Poliklinik Jiwa Anak dan Remaja RSUPN dr. Giptomangunkusumo [RSCM], Jakarta
}

\author{
Tjhin Wiguna, * Paul Samuel Kris Manengkei, ,* Christa Pamela, ${ }^{* *}$ \\ Agung Muhammad Rheza, ${ }^{* *}$ Windy Atika Hapsari** \\ * Divisi Psikiatri Anak dan Remaja, Departemen Psikiatri FKUI/RSUPN-CM \\ ** Mahasiswa S1, Fakultas Kedokteran Universitas Indonesia
}

Latar belakang. Anak dengan masalah emosi dan perilaku mempunyai kerentanan untuk mengalami hendaya dalam fungsi kehidupan sehari-hari, terutama dalam fungsi belajar dan sosialisasi. Masalah tersebut seringkali sulit dikenali oleh orangtua sehingga anak dengan masalah ini datang berobat dalam kondisi yang cukup berat.

Tujuan. Untuk mengetahui persepsi orangtua terhadap perubahan emosi dan perilaku pada anak mereka pada saat berkonsultasi di Poliklinik Jiwa Anak dan Remaja RSCM Jakarta selama periode November 2009-Mei 2010.

Metode. Penelitian deskriptif dengan menggunakan data sekunder dari catatan medik anak dan remaja di Poliklinik Anak dan Remaja RSCM, selama periode November 2009 - Mei 2010. Kriteria inklusi adalah, catatan medik lengkap mengenai data anak beserta orangtuanya, dan kuesioner Strength and Difficulties Questionaire (SDQ) diisi dengan lengkap.

Hasil. Selama periode enam bulan didapatkan 161 subjek penelitian yang memenuhi kriteria yang sudah ditentukan. Enam puluh lima koma sembilan puluh persen dari seluruh subjek penelitian berada pada usia kurang dari 12 tahun dan mempunyai tingkat pendidikan setara dengan sekolah dasar. Proporsi terbesar adalah masalah hubungan dengan teman sebaya $54,81 \%$, dan masalah emosional $42,2 \%$.

Kesimpulan. Masalah teman sebaya dan emosi merupakan masalah yang terbesar yang dijumpai pada pasien anak dan remaja yang datang berobat ke Poliklinik Jiwa Anak dan Remaja RSCM. Perlu dipertimbangkan untuk menerapkan suatu program keterampilan sosial di masyarakat atau sekolah sehingga diharapkan dapat menurunkan masalah ini di kemudian hari. Sari Pediatri 2010;12(4):270-7.

Kata kunci: emosi, perilaku, anak, SDQ.

\footnotetext{
Alamat korespondensi:

Dr. dr. Tjhin Wiguna, SpKJ(K), Staf Pengajar Divisi Psikiatri Anak dan Remaja, Departemen Psikiatri FKUI/RSCM, Jalan Kimia 2/35, Jakarta 10430. Telepon/Fax 021310741, 02139899128
}

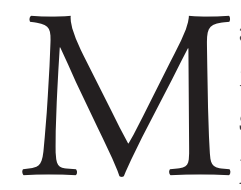

asalah emosi dan perilaku pada anak dan remaja merupakan masalah yang cukup serius karena berdampak terhadap perkembangan, serta menimbulkan 
Tjhin Wiguna dkk: Masalah emosi dan perilaku pada anak dan remaja di poliklinik jiwa anak dan remaja RSUPN dr. Ciptomangunkusumo (RSCM), Jakarta.

hendaya dan menurunkan produktivitas serta kualitas hidup mereka. Satu setengah juta anak dan remaja di Amerika Serikat dilaporkan oleh orangtuanya, memiliki masalah emosional, perkembangan, dan perilaku yang persisten. Sebagai contoh, $41 \%$ orang tua di Amerika Serikat khawatir anaknya mengalami kesulitan belajar dan 36\% khawatir akan mengalami gangguan depresi atau ansietas. ${ }^{1}$

Di Singapura, $12,5 \%$ anak usia 6-12 tahun memiliki masalah emosi dan perilaku. ${ }^{2}$ Salah satu faktor yang dikaitkan dengan timbulnya masalah ini adalah kehidupan di kota besar yang penuh dengan tuntutan dan tekanan bagi perkembangan dan pertumbuhan anak dan remaja, sedangkan faktor usia anak, jenis kelamin, dan perkerjaan orangtua hampir dikatakan tidak berpengaruh terhadap timbulnya masalah tersebut. ${ }^{3}$

Berbagai stresor psikososial seringkali dikaitkan dengan terjadinya masalah emosi dan perilaku pada anak dan remaja, seperti adanya penyakit fisik, pola asuh yang inadekuat, kekerasan dalam rumah tangga, hubungan dengan teman sebaya yang inadekuat, serta kemiskinan. Stresor psikososial tersebut mempengaruhi proses perkembangan kognitif anak sehingga anak lebih memandang negatif lingkungan sekitar dan juga persepsi yang negatif mengenai dirinya. Disamping itu, stresor psikososial juga berkaitan dengan peningkatan emosi negatif, perilaku disruptif dan impulsif, serta menimbulkan cara-cara interaksi yang negatif sehingga berdampak pada hubungan dengan teman sebaya yang tidak optimal. ${ }^{4,5}$

Masalah emosi dan perilaku yang terjadi berdampak terhadap tumbuh kembang dan kehidupan sehari-hari anak. Gangguan perkembangan kognitif, kesulitan dalam belajar karena mereka tidak mampu berkonsentrasi terhadap pelajaran, kemampuan mengingat yang buruk, atau bertingkah yang tidak sesuai di dalam lingkungan sekolah, akan meningkatkan angka kenakalan dan kriminalitas di masa dewasa. ${ }^{4}$

Anak dengan masalah emosi dan perilaku seringkali mengalami perlakukan yang tidak sesuai dari lingkungannya yang dapat berupa stigma negatif. Guru merasa sulit mengajari mereka, melihat mereka sebagai anak-anak bodoh, sehingga jarang memberikan masukan yang positif. Teman sebaya menjauhi mereka, sehingga kesempatan untuk belajar bersosialisasi menjadi berkurang. Orangtua lebih banyak memberikan kritik negatif sehingga tidak jarang interaksi antara orangtua dan anak menjadi terputus ${ }^{5,6}$

Melihat sedemikian luasnya faktor risiko dan dampak yang mungkin terjadi maka sudah sewajarnya orangtua atau guru harus lebih menyadari kondisi ini dengan melakukan deteksi dini sehingga masalah emosi dan perilaku pada anak dan remaja dapat ditangani sedini mungkin untuk menghindari terjadinya gangguan jiwa di kemudian hari. Dengan demikian, orangtua merupakan salah satu kunci penting dalam mendeteksi masalah emosi dan perilaku dan juga merupakan kunci keberhasilan tatalaksana yang akan diberikan pada anak mereka.

Penelitian ini bertujuan untuk menganalisis data yang berkaitan dengan persepsi orangtua terhadap perubahan emosi dan perilaku anak mereka pada saat berkonsultasi di Poliklinik Jiwa Anak dan Remaja RSCM, Jakarta selama periode November 2009 - Mei 2010 sehingga dapat memberikan gambaran seberapa jauh orangtua dapat mendeteksi masalah emosi dan perilaku pada anak mereka.

\section{Metode}

Telah dilakukan penelitian deskriptif dengan rancangan potong lintang. Data sekunder di peroleh dari catatan medik anak dan remaja yang berobat di Poliklinik Anak dan Remaja RSCM selama periode November 2009 Mei 2010. Maka subjek penelitian adalah seluruh anak dan remaja yang datang berobat di Poliklinik Anak dan Remaja RSCM dalam periode penelitian yang memenuhi kriteria inklusi yaitu catatan medik lengkap, berisi data anak beserta orangtuanya dan mengisi alat skrining SDQ dengan lengkap.

Skrining SDQ merupakan suatu alat yang dikembangkan oleh Robert Goodman pada tahun 1997, alat skrining tersebut sudah diterjemahkan ke dalam berbagai bahasa di dunia termasuk dalam Bahasa Indonesia. Skrining SDQ terdiri dari 25 buah pernyataan yang dapat dikelompokkan menjadi lima domain yaitu, (1) gejala emosional (5 pernyataan), (2) masalah conduct (5 pernyataan), (3) hiperaktivitas (5 pernyataan), (4) masalah hubungan dengan teman sebaya (5 pernyataan), dan (5) perilaku prososial (5 pernyataan). Setiap pernyataan dijawab oleh orangtua atau remaja dengan tidak pernah (skor 0), kadang benar (skor 1), dan selalu benar (skor 2). ${ }^{7}$

Hasil akhir penelitian menitikberatkan masalah 
emosi dan perilaku anak dan remaja, yaitu dengan menganalisis domain masalah emosi, masalah conduct, hiperaktivitas, dan masalah hubungan dengan teman sebaya, tanpa menganalisis skala prososial.

Sebelum analisis data dilakukan, pertama-tama dilakukan pembersihan data. Penilaian SDQ dilakukan dengan menjumlahkan angka-angka yang merupakan jawaban dari pertanyaan dalam alat skrining SDQ. Data yang terkumpul dimasukan ke dalam tabel, dilakukan pengolahan dengan menghitung skor yang tertinggi dan skor terendah untuk menentukan

Tabel 1. Sebaran subjek penelitian berdasarkan karakteristik demografis $(\mathrm{n}=161)$

\begin{tabular}{|c|c|c|}
\hline Karakteristik & Jumlah & Persentase \\
\hline \multicolumn{3}{|l|}{ Usia (tahun) } \\
\hline$<12$ & 106 & 65,9 \\
\hline $12-19$ & 49 & 30,4 \\
\hline Tidak ada data & 6 & 3,7 \\
\hline \multicolumn{3}{|l|}{ Jenis kelamin } \\
\hline Laki-laki & 97 & 60,2 \\
\hline Perempuan & 64 & 39,8 \\
\hline \multicolumn{3}{|l|}{ Agama } \\
\hline Islam & 140 & 87,0 \\
\hline Protestan & 12 & 7,5 \\
\hline Katolik & 1 & 0,6 \\
\hline Tidak ada data & 8 & 5,0 \\
\hline \multicolumn{3}{|c|}{ Suku bangsa menurut ayah } \\
\hline Jawa & 54 & 33,5 \\
\hline Sunda & 30 & 18,6 \\
\hline Betawi & 19 & 11,8 \\
\hline Minang & 13 & 8,1 \\
\hline Batak & 9 & 5,6 \\
\hline Lain-lain & 25 & 15,5 \\
\hline Tidak ada data & 11 & 6,8 \\
\hline \multicolumn{3}{|l|}{ Pendidikan } \\
\hline SD & 76 & 47,2 \\
\hline SMP & 26 & 16,1 \\
\hline SMA & 8 & 5,0 \\
\hline S1 & 0 & 0 \\
\hline S2 & 0 & 0 \\
\hline Lain-lain & 39 & 24,2 \\
\hline Tidak ada data & 12 & 7,5 \\
\hline
\end{tabular}

distribusi frekuensi. Hasil akhir disajikan dalam bentuk tabular dan tekstular.

\section{Hasil}

Selama periode enam bulan didapatkan 161 subjek penelitian yang memenuhi kriteria yang sudah ditentukan. Enam puluh lima koma sembilan puluh persen dari seluruh subjek penelitian berada pada usia kurang dari 12 tahun dan mempunyai tingkat pendidikan setara dengan sekolah dasar. Proporsi subjek penelitian dengan jenis kelamin laki-laki lebih banyak daripada perempuan (Tabel 1).

Proporsi terbesar usia ayah subjek di atas 40 tahun $(60,9 \%)$ dan usia ibu di bawah 40 tahun $(53,4 \%)$. Proporsi tingkat pendidikan tertinggi ayah dan ibu adalah SMA (44,1\% dan 41,6\%). Umumnya orangtua subjek penelitian berasal dari kelompok sosial ekonomi menengah berdasarkan tingkat pendapatan keluarga $(76,4 \%)$ dan bekerja sebagai pegawai swasta (49,1\%).

Proporsi terbesar adalah masalah hubungan dengan teman sebaya $54,81 \%$, dan masalah emosional $42,2 \%$ (Tabel 2). Anak yang berusia kurang dari 12 tahun lebih banyak mengalami masalah hubungan dengan teman sebaya $(39,1 \%)$, sedangkan remaja lebih banyak mengalami masalah emosi (33,5\%) (Gambar 1). Anak

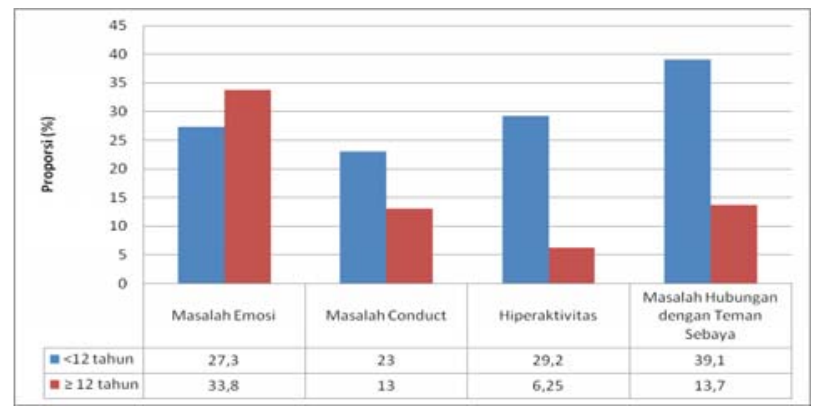

Gambar 1. Proporsi masalah emosi dan perilaku berdasarkan kelompok usia dan domain masalah $(\mathrm{n}=155)$

Tabel 2. Sebaran karakteristik masalah emosi dan perilaku subjek penelitian berdasarkan SDQ ( $\mathrm{n}=161)$

\begin{tabular}{lccc}
\hline Masalah emosi dan perilaku & Normal (\%) & Borderline (\%) & Abnormal (\%) \\
\hline Masalah emosi & $75(46,6)$ & $18(11,2)$ & $68(42,2)$ \\
Masalah conduct & $70(43,5)$ & $29(18,0)$ & $62(38,5)$ \\
Hiperaktivitas & $75(45,1)$ & $28(16,8)$ & $57(38,1)$ \\
Masalah hubungan dengan teman sebaya & $60(36,1)$ & $15(9,1)$ & $86(54,8)$ \\
\hline
\end{tabular}


Tjhin Wiguna dkk: Masalah emosi dan perilaku pada anak dan remaja di poliklinik jiwa anak dan remaja RSUPN dr. Ciptomangunkusumo (RSCM), Jakarta.

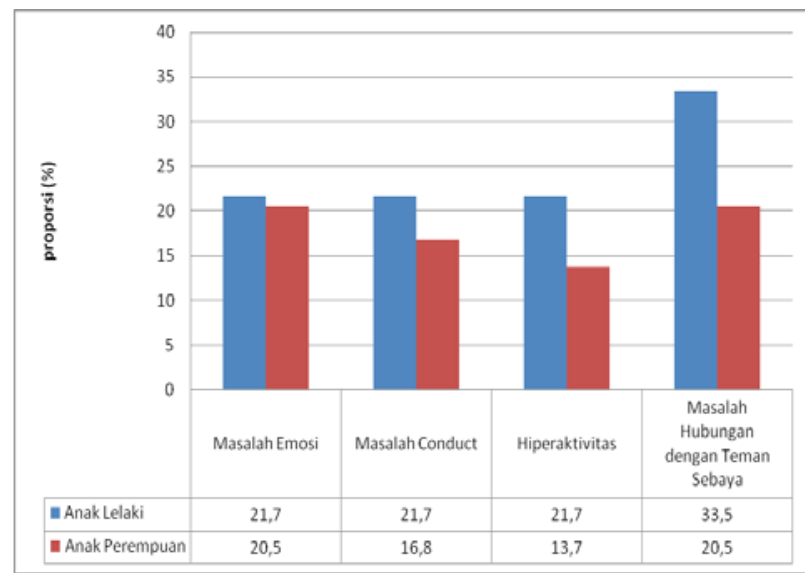

Gambar 2. Proporsi masalah emosi dan perilaku berdasarkan jenis kelamin dan domain masalah $(\mathrm{n}=161)$

lelaki lebih banyak mengalami masalah hubungan dengan teman sebaya, sedangkan anak perempuan lebih banyak mengalami masalah emosi dan juga masalah hubungan dengan teman sebaya $(20,5 \%)$ (Gambar 2).

\section{Pembahasan}

Berdasarkan hasil penelitian didapatkan beberapa data yang menarik untuk didiskusikan. Orangtua lebih banyak mengeluhkan masalah hubungan dengan teman sebaya $(54,8 \%)$ sebagai masalah utama anak mereka yang berkonsultasi di Poliklinik Jiwa Anak dan Remaja RSCM Jakarta. Permasalahan ini terutama dijumpai pada anak lelaki yang masih berusia di bawah 12 tahun.

Orangtua mempunyai persepsi bahwa masalah hubungan dengan teman sebaya merupakan masalah yang cukup serius, terutama anak yang memasuki usia remaja. Teman sebaya bagi anak yang berusia 9-13 tahun, paling besar pengaruhnya terhadap kehidupan mereka sehari-hari disamping orangtua. ${ }^{6}$ Dengan adanya masalah hubungan dengan teman sebaya ini tentunya berdampak dalam fungsi keseharian anak dan remaja sehingga membuat orangtua menjadi lebih waspada dan membawa mereka untuk datang berkonsultasi oleh karena adanya hendaya dalam interaksi sehari-hari.

Masalah emosi merupakan masalah kedua dengan proporsi cukup besar $(42,2 \%)$ yang dikemukakan oleh orangtua. Masalah emosi dalam SDQ mencakup masalah depresi dan juga cemas. Garland $(2001)^{8}$ melaporkan bahwa 33,6\% anak yang datang ke pusat pelayanan kesehatan jiwa dengan masalah emosi. Angka yang didapatkan dalam penelitian kami sedikit lebih tinggi daripada angka yang didapatkan oleh penelitian yang dilakukan oleh Garland. Anak perempuan di bawah usia 12 tahun ternyata mengalami masalah emosi yang lebih banyak pada penelitian kami, kondisi ini sesuai dengan penelitian yang telah dilakukan di berbagai negara. ${ }^{9}$ Masalah emosi yang dinilai termasuk gejala depresi dan cemas, karena dalam periode usia ini anak mengalami krisis perkembangan. Anak mengalami perubahan hormonal dan juga perubahan sikap lingkungan sehingga lebih memicu terjadinya masalah emosi bagi anak dengan kerentanan tertentu.

Masalah conduct juga merupakan masalah perilaku yang dijumpai pada anak dan remaja dengan proporsi yang cukup besar terutama pada kelompok remaja. Namun dijumpai proporsi yang lebih tinggi pada anak di bawah usia 12 tahun, dan hasil ini berbeda dengan berbagai hasil yang ditemukan dalam penelitian di luar negeri. ${ }^{1,3,10}$ Beberapa hal yang mungkin berkaitan dengan kondisi tersebut adalah RSUPNCM merupakan rumah sakit rujukan yang sudah lama memberikan pelayanan kesehatan jiwa sehingga lebih banyak anak dengan masalah conduct berkonsultasi; orangtua sudah lebih waspada dengan berbagai masalah conduct sehingga mereka mencari pertolongan yang lebih dini sebelum anak memasuki usia remaja; adanya penggeseran perkembangan masa remaja ke usia yang lebih awal sehingga masalah sudah tampak di periode remaja awal.

Terdapat beberapa hal yang menjadi hipotesis sehubungan dengan didapatkannya berbagai data yaitu, 1) adanya tantangan hidup termasuk tantangan di sekolah yang bertambah besar sehingga anak dan remaja lebih banyak menginternalisasikan (dalam bentuk masalah emosi) dan mengkesternalisasikan (dalam bentuk masalah conduct dan hubungan dengan sebaya) berbagai konflik yang ada dalam diri mereka; 2) isu globalisasi sehingga arus informasi yang datang begitu banyak dan anak dan remaja belum menghadapinya dengan baik; dan 3) berbagai krisis di kota besar yang berdampak dalam perkembangan emosi anak dan remaja. Tentunya semua kondisi tersebut masih perlu dilakukan pengkajian lebih lanjut. 
Tjhin Wiguna dkk: Masalah emosi dan perilaku pada anak dan remaja di poliklinik jiwa anak dan remaja RSUPN dr. Ciptomangunkusumo (RSCM), Jakarta.

Penelitian kami tidak mencari berbagai faktor yang berkaitan dengan terjadinya masalah emosi dan perilaku. Disamping itu SDQ merupakan suatu alat skrining yang diisi oleh orangtua maupun remaja sehingga dapat terjadi bias pengisian yang tentunya sangat berpengaruh terhadap hasil penelitian. Untuk itu disarankan agar melakukan penelitian yang juga memasukan berbagai faktor risiko yang mungkin berkaitan dengan terjadinya masalah emosi dan perilaku pada anak dan remaja di kemudian hari sehingga wawasan kita mengenai kondisi ini bertambah banyak.

\section{Daftar pustaka}

1. Blanchard LT, Gurka MJ, Blackman JA. Emotional, developmental, and behavioral health of American children and teir families: A report from the 2003 national survey of children's health. Pediatrics.2006;117:120212.

2. Woo BSC, Ng TP, Fung DSS, Chan YH, Lee YP, Koh JBK, dkk. Emotional and behavioral problems in Singaporean children based on parent, teacher, and child reports. Singopre Med J. 2007;48:1100-6.

3. Erol N, Simsek Z, Oner O, Munir K. Behavioral and emotional problemsamong Turkish children at ages 2 to 3 years. J Am Acad Child Adolesc Psychiatry
2005;44:80-5.

4. Gimpel GA. Holland ML. Emotional and behavioral problmes in young children: effective interventions in the preschool and kindergarten years. New York: Guilford; 2003.h.112-3.

5. Gelder MG, Lopez Ibor JJ, Andreasen N. New oxford textbook of psychiatry. Oxford University Press; 2003. h. 123-5

6. Collett, B. R., Gimpel, G. A., Greenson, J. N., \& Gunderson, T. L. Assessment of discipline styles among parents of preschool through school-age children. J Psychopathol and Behavior Assess 2001;23:163-170.

7. Goodman R. The stregth and difficulties questionaire: A research note. J Child Psychol Psychiatry. 1997;38:581-6

8. Garland AF, dkk. Prevalence of psychiatric disorders in youth across five sectors of care. J Am Acad Child Adolesc Psy 2001;40:409-18.

9. Verhulst FC. Epidemiology as a basis for conception and planning for services. Dalam: Remschmidt H, Belfer ML, Goodyer I, penyunting. Facilitating pathways care, treatment and prevention in child and adolescent mental health. Germany: Springer; 2004. h.3-15.

10. Fox L, Dunlap G, Powell D. Young children with challenging behavior: Issues and consideration for behaviora problem support. Journal of Positive Behavior Intervention. 2002:4:208-17 
Tjhin Wiguna dkk: Masalah emosi dan perilaku pada anak dan remaja di poliklinik jiwa anak dan remaja RSUPN dr. Ciptomangunkusumo (RSCM), Jakarta.

\section{Lampiran SDQ}

SDQ untuk anak berusia 4-16 tahun yang diisi orangtua

\section{Kuesioner Kekuatan dan Kesulitan Pada Anak}

Untuk setiap pernyataan, beri tanda pada kotak Tidak Benar, Agal Benar atau Benar. Alan sangat membantu kami apabila andamau menjawab semua pernyataan sebaik mungkin meskipun anda tidak yakin benar. Berikan jawaban anda menurut perilakuanalk itu selama enam bulan terakhir atau selama tahun ajaran ini.

Nama anak

Laki-laki/Perempuan

Tanggal labir

\begin{tabular}{|c|c|c|c|}
\hline & $\begin{array}{l}\text { Tidal } \\
\text { Benar }\end{array}$ & $\begin{array}{c}\text { Agalk } \\
\text { Benar }\end{array}$ & Benar \\
\hline Dapat memperdulikan perasaan orang lain & & L & \\
\hline Gelisah, terlalu aktif, tidak dapat diam untuk waktu lama & & & \\
\hline Sering mengeluh sakit kepala, sakit perut atau sakit-sakit lainnya & & ᄂ & \\
\hline $\begin{array}{l}\text { Kalau mempunyai mainan, kesenangan, atau pensil, anak bersedia berbagi dengananak-anak } \\
\text { lain }\end{array}$ & & L & L \\
\hline Sering sulit mengendalikan kemarahan & & $\square$ & \\
\hline Cenderung menyendiri, lebih suka bermain seorang diri & & $\square$ & ᄂ \\
\hline Umumnya bertingkah laku baik, biasanya melakukan apa yang disuruh oleh orangdewasa & & 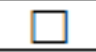 & \\
\hline Banyak kekbawatiran atau sering tampak khawatir & & 난 & ㄴ. \\
\hline Suka menolong jika seseorang terluka, kecewa atau merasa sakit & & & \\
\hline Terus menerus bergerak dengan resah atau menggeliat-geliat & & & \\
\hline Mempunyai satu atau lebih teman baik & & 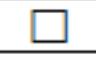 & \\
\hline Sering berkelahi dengan anak-anak lain atau mengintimidasi mereka & & & \\
\hline Sering merasa tidak bahagia, sedih atau menangis & & & \\
\hline Pada umumnya disukai oleh anak-anak lain & & & \\
\hline Mudah teralih perhatiannya, tidak dapat berkonsentrasi & & & 5 \\
\hline $\begin{array}{l}\text { Gugup atau sulit berpisah dengan orang tua/pengasubnya pada situasi baru, } \\
\text { mudahkehilangan rasa percaya diri }\end{array}$ & & & \\
\hline Bersikap baik terhadap anak-anak yang lebih muda & & & \\
\hline Sering berbohong atau berbuat curang & & 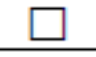 & \\
\hline Diganggu, di permainkan, di intimidasi atau di ancam oleh anak-anak lain & ᄂ & $\square$ & ᄂ \\
\hline Sering menawarkan diri untuk membantu orang lain (orang tua, guru, anak-anak lain) & & $\square$ & \\
\hline Sebelum melakukan sesuatu ia berpikir dahulu tentang akibatnya & $\square$ & $\square$ & \\
\hline Mencuri dari rumah, sekolah atau tempat lain & $\square$ & $\square$ & L \\
\hline Lebih mudah berteman dengan orang dewasa daripada dengan anak-analk lain & $\square$ & $\square$ & L \\
\hline Banyak yang ditakuti, mudah menjadi takut & $\square$ & $\square$ & 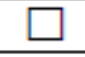 \\
\hline $\begin{array}{l}\text { Memiliki perhatian yang baik terbadap apapun, mampu menyelesaikan tugas ataupekerjaan } \\
\text { rumah sampai selesai }\end{array}$ & $\square$ & $\square$ & 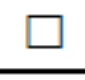 \\
\hline
\end{tabular}

Tanda tangan

Tanggal

Sari Pediatri, Vol. 12, No. 4, Desember 2010 
Tjhin Wiguna dkk: Masalah emosi dan perilaku pada anak dan remaja di poliklinik jiwa anak dan remaja RSUPN dr. Ciptomangunkusumo (RSCM), Jakarta.

SDQ untuk anak berusia $11-17$ tahun yang dapat diisi sendiri oleh remaja

\section{Kuesioner Kekuatan dan Kesulitan Pada Anak}

Untuk setiap pernyataan, beri tanda V pada kotak Tidak Benar, Agak Benar atau Benar. Akan sangat membantu kami apabilakamu mau menjawab senua pernyataan sebaik mungkin meskipun kamu tidak yakin benar. Berikan jawabanmu menurutbagaimana segala sesuatu telah terjadi pada dirimu selama enam bulan terakhir.

Nama .

Laki-laki/Perempuan

Tanggal labir

\begin{tabular}{|c|c|c|c|}
\hline & $\begin{array}{l}\text { Tidak } \\
\text { Benar } \\
\end{array}$ & $\begin{array}{l}\text { Agalk } \\
\text { Benar } \\
\end{array}$ & Benar \\
\hline Saya berusaha bersikap baik kepada orang lain. Saya peduli dengan perasaan mereka & & & \\
\hline Saya gelisah, saya tidak dapat diam untuk waktu lama & & & \\
\hline Saya sering sakit kepala, sakit perut atau macam-macam sakit lainnya & & & \\
\hline Kalau saya memiliki mainan, $C D$, atau makanan, saya biasanya berbagi dengan orang la & & & \\
\hline Saya menjadi sangat marah dan sering tidak dapat mengendalikan kemaraban saya & & & \\
\hline Saya lebih suka sendirian daripada bersama dengan orang-orang yang seumur saya & & & \\
\hline Saya biasanya melakukan apa yang diperintahkan oleh orang lain & & & \\
\hline Saya banyalk merasa cemas atau kbawatir terbadap apa pun & & & \\
\hline Saya selalu siap menolong jika ada orang yang terluka, kecewa, atau merasa sakit & & & \\
\hline Bila sedang gelisah atau cemas, badan saya sering bergerak-gerak tampa saya sadari & & & \\
\hline Saya mempunyai satu orang teman baik atau lebih & & & \\
\hline $\begin{array}{l}\text { Saya sering bertengkar dengan orang lain. Saya dapat memaksa orang lain melakulkanap } \\
\text { yang saya inginkan }\end{array}$ & & & \\
\hline Saya sering merasa tidak bahagia, sedib atau menangis & & & \\
\hline Orang lain seumur saya pada umumnya menyukai saya & & & \\
\hline Perhatian saya mudah teralihkan, saya sulit memusatkan perhatian pada apa pun & & & \\
\hline Saya merasa gugup dalam situasi baru, saya mudah kehilangan rasa percaya diri & & & \\
\hline Saya bersikap baik terbadap anak-analk yang lebih muda dari saya & & & \\
\hline Saya sering dituduh berbohong atau berbuat curang & & & \\
\hline Saya sering diganggu atau dipermainkan oleh anak-anak atau remaja lainnya & & & \\
\hline Saya sering menawarkan diri untuk membantu orang lain (orang tua, guru, anak-anak) & & & \\
\hline Sebelum melakukan sesuatu saya berpikir dahulu tentang akibatmya & & & \\
\hline Saya mengambil barang yang bukan milik saya dari rumah, sekolah atau dari mana saja & & & \\
\hline $\begin{array}{l}\text { Saya lebih mudah berteman dengan orang dewasa daripada dengan orang-orang yangse } \\
\text { saya }\end{array}$ & & & \\
\hline Banyak yang saya takuti, saya mudah menjadi takut & $\square$ & $\square$ & 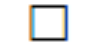 \\
\hline
\end{tabular}

Tanda tangan

Tanggal hari ini 
Tjhin Wiguna dkk: Masalah emosi dan perilaku pada anak dan remaja di poliklinik jiwa anak dan remaja RSUPN dr.

Ciptomangunkusumo (RSCM), Jakarta.

\begin{tabular}{|c|}
\hline $\begin{array}{l}\text { Pertanyaan/ } \\
\text { Kode* }\end{array}$ \\
\hline 1. $\operatorname{Pr} 1$ \\
\hline 2. $\mathrm{H} 1$ \\
\hline 3. E 1 \\
\hline 4. $\operatorname{Pr} 2$ \\
\hline 5. C 1 \\
\hline 6. $\quad$ P 1 \\
\hline 7. C 2 \\
\hline 8. E 2 \\
\hline 9. $\operatorname{Pr} 3$ \\
\hline 10. H 2 \\
\hline 11. P 2 \\
\hline 12. C 3 \\
\hline 13. E 3 \\
\hline 14. P 3 \\
\hline 15. H 3 \\
\hline 16. E 4 \\
\hline 17. $\operatorname{Pr} 4$ \\
\hline 18. C 4 \\
\hline 19. P 4 \\
\hline 20. $\operatorname{Pr} 5$ \\
\hline 21. H4 \\
\hline 22. C 5 \\
\hline 23. P 5 \\
\hline 24. E 5 \\
\hline 25. H 5 \\
\hline
\end{tabular}

Penilaian;

1. Untuk anak berusia 4 - 10 tahun diisi oleh orangtua dengan nilai batas sebagai berikut;

\begin{tabular}{|l|l|l|l|}
\hline \multicolumn{1}{|c|}{ Nilai } & Normal & Borderline & Abnormal \\
\hline & & & \\
\hline Perilaku pro-sosial & $6-10$ & 5 & $0-4$ \\
\hline Masalah Emosional & $0-3$ & 4 & $5-10$ \\
\hline Masalah Conduct & $0-2$ & 3 & $4-10$ \\
\hline Hiperaktivitas & $0-5$ & 6 & $7-10$ \\
\hline $\begin{array}{l}\text { Masalah Hubungan } \\
\text { dengan Teman Sebaya }\end{array}$ & $0-2$ & 3 & $4-10$ \\
\hline
\end{tabular}

2. Untuk anak berusia 11 - 17 tahun dapat diisi sendiri dengan nilai batas sebagai berikut;

\begin{tabular}{|l|l|l|l|}
\hline \multicolumn{1}{|c|}{ Nilai } & Normal & Borderline & Abnormal \\
\hline Perilaku pro-sosial & & & \\
\hline Masalah Emosional & $6-10$ & 5 & $0-4$ \\
\hline Masalah Conduct & $0-5$ & 6 & $7-10$ \\
\hline Hiperaktivitas & $0-3$ & 4 & $5-10$ \\
\hline $\begin{array}{l}\text { Masalah Hubungan dengan } \\
\text { Teman Sebaya }\end{array}$ & $0-3$ & 6 & $7-10$ \\
\hline
\end{tabular}

* $\mathbf{E}=$ emotional; $\mathbf{C}=$ conduct problems; $\mathbf{H}=$ hyperactivity; $\mathbf{P}=$ peer problems; $\mathbf{P r}=$ prosocial

Sari Pediatri, Vol. 12, No. 4, Desember 2010 